\title{
Efficacy of several larvicides in laboratory and field tests against Anopheles sundaicus in a village, North Sumatra, Indonesia
}

\author{
Chobei Imai, ${ }^{*}$ Hisao Yamugi ${ }^{* *}$ and Willem Panjaitan ${ }^{* * *}$ \\ * Osaka City Institute of Public Health and Environmental Sciences, \\ Tennoji-ku, Osaka 543, Japan \\ ** Eikou Kagaku, Tennoji-ku, Osaka 543, Japan \\ ${ }^{* * *}$ Provincial Health Service of North Sumatra, Jalan Prof. H. M. Yamin SH, \\ Medan, Indonesia
}

(Received: September 1, 1986)

Key words: Anopheles sundaicus larva, North Sumatra, methoprene, temephos, chlorpyrifosmethyl, organophosphorus insecticide.

\begin{abstract}
Laboratory and field evaluation of larvicides was carried out against Anopheles sundaicus in a coastal village of North Sumatra, Indonesia in 1984 and 1985. The 4th instar larvae were highly susceptible to methoprene $\left(\mathbf{I C}_{50}=0.00009 \mathrm{ppm}\right)$, and susceptible to temephos $\left(\mathbf{L G}_{50}=0.0032 \mathrm{ppm}\right)$ and chlorpyrifos-methyl $\left(\mathrm{LG}_{50}=0.0037 \mathrm{ppm}\right)$. However, they seemed to be a little tolerant to fenitrothion $\left(\mathrm{LC}_{50}=0.015 \mathrm{ppm}\right)$ and fenthion $\left(\mathrm{LC}_{50}=0.025 \mathrm{ppm}\right)$. Temephos 5\% wp was effective to suppress larval densities almost completely for at least 9 days at a target concentration of $1 \mathrm{ppm}$. Practical efficacy of this chemical was considered to remain for at least 2 weeks, taking the developmental period of the immatures into account. Chlorpyrifos-methyl 5\% wp was effective to control larval densities almost completely for 7 days, and fenitrothion $50 \% \mathrm{EC}$ was effective for less than 5 days after $1 \mathrm{ppm}$ field application. Field application of methoprene $10 \%$ flowable formulation (Altosid 10F) attained more than $90 \%$ emergence inhibition against the immatures for 2 weeks in artificial ditch type ponds at $1 \mathrm{ppm}$ target concentration, and $100 \%$ inhibition for 4 weeks in a natural flood field at $0.062 \mathrm{~g}$ a. $\mathrm{i} . / \mathrm{m}^{2}$ dose.
\end{abstract}

\section{INTRODUCTION}

Anopheles sundaicus is the main vector of malaria in the coastal areas of Indonesia (Sundararaman et al., 1957) including North Sumatra (Swellengrebel and Rodenwaldt, 1932; Lien et al., 1975). Operational evaluation of some larvicides against this

* 今井長兵衛：大阪市立環境科学研究所 (兵543大 阪市天王寺区東上町 8-34)

** 矢麦寿雄：エイコー科学（元543 大阪市天王寺区 大道 3-8-27) species has been conducted in Java (Schaefer and Kirnowardoyo, 1983) and Bali (ten Houten et al., 1980; Sudomo et al., 1981).

In North Sumatra, a malaria vector control study has been carried out in the coastal areas of the Asahan district since 1978, as a main activity of the North Sumatra Health Promotion Project under the cooperation between Indonesian and Japanese governments. An. sundaicus was determined as a target species for vector control operation based on the results of epidemiological and entomological studies (Ikemoto, 1982; Kan- 
bara and Panjaitan, 1983). Laboratory and small-scale field tests of larvicides were conducted against this mosquito at a pilot village, Perupuk. Ikemoto et al. (1986) reported that temephos was a promising larvicide but that Bacillus thuringiensis israelensis preparation (B.t.i.) lost its efficacy shortly in the field.

In this paper, we report the results of further study on the efficacy of four organophosphorus larvicides and an insect growth regulator, methoprene, against $A n$. sundaicus in Perupuk village.

\section{Materials and Methods}

\section{Laboratory tests.}

Chemicals tested were alcohol solutions of temephos, fenitrothion and fenthion, and wettable powder (wp) of $5 \%$ chlorpyrifosmethyl. Technical grade of methoprene and its $10 \%$ flowable formulation (Altosid 10F) were also used.

An. sundaicus larvae collected from brackish ponds at Perupuk village (Fig. 1) in October 1984 and May 1985 were used after laboratory rearing for 2-5 days.

Twenty individuals of 4 th instar larvae were placed in a cup containing $100 \mathrm{ml}$ water with a desired concentration of each insecticide. Seven or 8 grades of concentration were prepared for each chemical and 3-6 replications were made for each concentration. Observations for mortality were made after $24 \mathrm{hr}$ in the tests of organophosphorus compounds. In the tests of methoprene, larvae were continuously exposed to the chemical. Most of them pupated within 1st day after the beginning of exposure. Numbers of adults emerged were recorded till 5 th day. During the periods of these tests, water temperature was $26-28^{\circ} \mathrm{C}$.

Values of $\mathrm{LC}_{50}$ (50\% lethal concentration) or $\mathrm{IC}_{50} \quad(50 \%$ emergence inhibition concentration) were estimated from the relation between $\log$ concentration and probit mortality or inhibition.

2. Field tests.

Insecticides: Temephos 5\% wp, fenitrothion $50 \%$ emulsifiable concentrate (EC), chlorpyrifos-methyl $5 \% \mathrm{wp}$, and methoprene $10 \%$ flowable formulation were used.

Ponds used for test: Fourteen ponds, A$\mathrm{N}$, situating on the coast of Perupuk village (Fig. 1) were selected for the field tests of the chemicals. Their characteristics are sum-

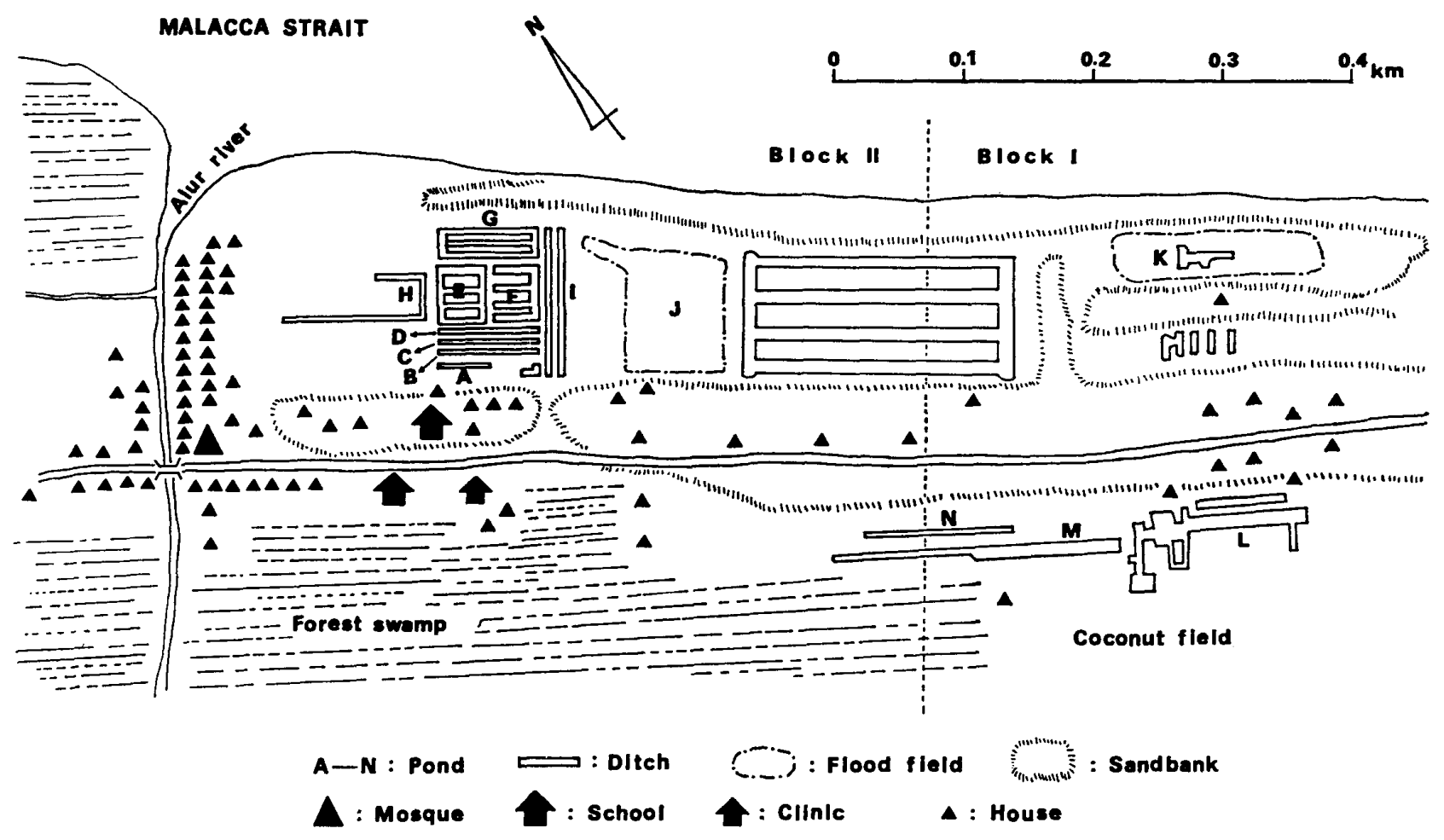

Fig. 1 Sketch map of field trial area in Perupuk village. 
marized in Table 1. Ponds A-I were irrigation ditches constructed with soil for coconut cultivation, situating closely with each other. Pond $\mathrm{J}$ was a shallow but wide flood area with natural thin forests and low grasses. Pond $\mathrm{K}$ consisted of narrow irrigation ditches and wide flood area with low grasses. Ponds $\mathrm{L}-\mathrm{N}$ were old irrigation ditches surrounded with high coconut trees. Ponds $\mathrm{K}-\mathrm{N}$ were situated nearby with each other. These ponds were favorable habitats for $A n$. sundaicus before the field tests.

Application: The formulation of each chemical was diluted with water as follows: 100 -fold in $5 \%$ wp of temephos and chlorpyrifos-methyl, 500 -fold in $50 \%$ fenitrothion EC, and 200-fold in 10\% methoprene. Those were sprayed on water surface of the ponds with sprinkling cans and dippers at the target concentration of $1 \mathrm{ppm}$ active ingredient per water body except for methoprene treatment in pond $\mathrm{J}$, where the target dose was $0.062 \mathrm{~g}$ a.i. $/ \mathrm{m}^{2}$ of water surface.

Evaluation: The efficacy of organophosphates was evaluated by comparing the densities of $A n$. sundaicus larvae between pre- and post-spray periods and/or between sprayed and unsprayed ponds. The density was estimated as the number of larvae collected per 20 times dipping with a dipper of $18 \mathrm{~cm}$ diameter and $10 \mathrm{~cm}$ depth.

The efficacy of methoprene was examined by comparing emergence inhibition rates of field collected immatures between pre- and post-treatment periods and/or between treated and untreated ponds. Fully-grown larvae were collected from the ponds under test and reared for 1 week in the water of the very ponds under laboratory conditions. The emergence inhibition rate was expressed as 1 -emergence rate.

Temephos trial: We planned 3 field trials. The first trial was carried out for 9 ponds, A-I, from 16 October to 5 December 1984. The temephos application was made 2 times; namely on 24 October (the first application) and 14 November (the second application) to 3 ponds, $\mathrm{B}, \mathrm{E}$ and $\mathrm{F}$. Only the first application was made to pond $\mathrm{C}$, and only the second one was done to 3 ponds, D, G and $H$. The remaining 2 ponds, $A$ and $I$, were used as control untreated ponds. The larval densities were examined 18 times in the trial period.

Table 1 Characteristics of 14 ponds used for field tests.

\begin{tabular}{|c|c|c|c|c|c|c|c|c|}
\hline \multirow{3}{*}{ Pond } & \multirow{3}{*}{$\begin{array}{c}\text { Type of } \\
\text { water body }\end{array}$} & \multicolumn{2}{|c|}{ Maximum size } & \multirow{3}{*}{$\begin{array}{l}\text { Larval } \\
\text { index }\end{array}$} & \multicolumn{4}{|c|}{ Conditions during field test } \\
\hline & & \multirow{2}{*}{$\begin{array}{l}\text { Area } \\
\left(\mathrm{m}^{2}\right)\end{array}$} & \multirow{2}{*}{$\underset{\left(\mathrm{m}^{3}\right)}{\text { Volume }}$} & & \multicolumn{2}{|c|}{ Water depth $(\mathrm{cm})$} & \multicolumn{2}{|c|}{ Salinity $(\%)$} \\
\hline & & & & & Average & Range & Average & Range \\
\hline A & D (Ditch) & 105 & 63 & 3.4 & 46 & $30-63$ & 1.32 & $0.69-2.31$ \\
\hline $\mathrm{B}$ & D & 115 & 55 & 10.6 & 39 & $29-53$ & 1.23 & $0.71-2.35$ \\
\hline $\mathrm{C}$ & $\mathrm{D}$ & 135 & 68 & 7.6 & 40 & $32-54$ & 1.29 & $0.75-2.31$ \\
\hline $\mathrm{D}$ & $\mathrm{D}$ & 131 & 65 & 13.6 & 36 & $30-54$ & 1.35 & $0.62-2.28$ \\
\hline $\mathrm{E}$ & $\mathrm{D}$ & 835 & 290 & 13.2 & 24 & $11-40$ & 1.42 & $0.66-2.53$ \\
\hline $\mathrm{F}$ & $\mathrm{D}$ & 276 & 95 & 10.6 & 24 & $13-37$ & 1.41 & $0.81-2.56$ \\
\hline $\mathrm{G}$ & $\mathrm{D}$ & 1,550 & 540 & 15.2 & 22 & $12-36$ & 1.49 & $0.76-2.33$ \\
\hline $\mathrm{H}$ & $\mathrm{D}$ & 230 & 70 & 24.4 & 20 & $11-37$ & 1.41 & $0.67-2.43$ \\
\hline I & $\mathrm{D}$ & 260 & 115 & 5.2 & 44 & $49-48$ & 1.35 & $0.81-2.17$ \\
\hline $\mathrm{J}$ & F (Flood field) & 8,900 & - & $20.5^{*}$ & - & - & 1.37 & $0.97-2.27$ \\
\hline $\mathrm{K}$ & $D+F$ & 2,570 & 605 & 89.2 & 57 & $38-70$ & 0.81 & $0.36-1.65$ \\
\hline $\mathrm{L}$ & $\mathrm{D}$ & 1,060 & 490 & 43.2 & 47 & $31-58$ & 0.48 & $0.13-1.25$ \\
\hline$M$ & $\mathrm{D}$ & 500 & 130 & 17.4 & 71 & $50-80$ & 0.98 & $0.85-1.05$ \\
\hline $\mathrm{N}$ & $\mathrm{D}$ & 250 & 65 & $34.8^{* *}$ & 35 & $24-41$ & 0.91 & $0.67-1.20$ \\
\hline
\end{tabular}

Larval index: average number of Anopheles sundaicus larvae collected per 20 dips in 5 times survey from 21 August to 23 October 1984. * Data based on 4 times survey from 20 February to 9 April 1985; ** Data based on 5 times survey from 6 March to 21 May 1985. 
The second trial was carried out for 8 ponds, A-H, from 5 December 1984 to 8 January 1985 . The application was made to 4 ponds, D, E, $\mathrm{G}$ and $\mathrm{H}$, on 6 December 1984. The remaining 4 ponds, $\mathrm{A}, \mathrm{B}, \mathrm{G}$ and $\mathrm{F}$, were used as control untreated ponds. The larval densities were estimated 7 times in the trial period.

The third trial was conducted for 2 ponds, $\mathrm{K}$ and L, from 13 November to 18 December, 1984. The application was made to pond $\mathrm{K}$ on 14 November. Pond $\mathrm{L}$ was used as a control untreated pond. The larval densities were estimated 13 times in the trial period.

Fenitrothion trial: The application was made to pond $\mathrm{K}$ on 12 June 1985 after the population estimation on 21 May and 11 June. The post-treatment estimation was done on 13, 17 and 26 June.

Chlorpyrifos-methyl trial: Following the estimation of larval densities on 21 May and 4 June 1985, the application was made on 5 June to 2 ponds, $M$ and $N$. The post- treatment estimation was done on $6,12,17$ and 26 June.

Methoprene trial: After one pre-treatment estimation of emergence inhibition rates on 15 April 1985, the application was made on 16 April to 3 ponds $E, F$ and $G$, and on 23 April to pond J. The post-treatment evaluation was made 1 day after the application for three ponds except pond J, and thereafter once every week till the 5 th week in ponds $E, F$ and $G$, and till the 6 th week in pond J. Emergence failure rates of the immatures in untreated ponds $\mathrm{K}$ and $\mathrm{L}$ were also estimated by using larvae collected on the same dates as in the treated ponds till the 5 th week.

\section{Results}

\section{Laboratory tests}

Table 2 shows the susceptibility status of $A n$. sundaicus larvae. The $\mathrm{LC}_{50}$ values were estimated to be $0.0032 \mathrm{ppm}$ for temephos, $0.0037 \mathrm{ppm}$ for chlorpyrifos-methyl, 0.015

Table 2 Efficacy of 4 organophosphorus insecticides against Anopheles sundaicus larvae in laboratory tests.

\begin{tabular}{|c|c|c|c|c|c|c|c|c|}
\hline \multirow{3}{*}{$\begin{array}{l}\begin{array}{c}\text { Concentration } \\
\text { of chemical } \\
\text { (ppm) }\end{array} \\
0.08\end{array}$} & \multicolumn{8}{|c|}{ Percent mortality } \\
\hline & \multicolumn{2}{|c|}{$\begin{array}{l}\text { Temephos } \\
\text { Oct. } 1984\end{array}$} & \multicolumn{2}{|c|}{$\begin{array}{l}\text { Fenitrothion } \\
\text { Oct. } 1984\end{array}$} & \multicolumn{2}{|c|}{$\begin{array}{l}\text { Fenthion } \\
\text { Oct. } 1984\end{array}$} & \multicolumn{2}{|c|}{$\begin{array}{c}\text { Chlorpyrifos-methyl } \\
\text { May } 1985\end{array}$} \\
\hline & 100 & $(58)$ & 100 & $(60)$ & 97.3 & $(75)$ & & \\
\hline 0.05 & & & & & & & 100 & $(72)$ \\
\hline 0.04 & 100 & $(60)$ & 96.2 & (52) & 96.2 & $(52)$ & & \\
\hline 0.025 & & & & & & & 100 & $(80)$ \\
\hline 0.02 & 98.1 & (105) & 71.8 & $(78)$ & 20.0 & $(100)$ & & \\
\hline 0.013 & & & & & & & 100 & $(79)$ \\
\hline 0.01 & 90.4 & (94) & 30.7 & $(101)$ & 11.9 & $(101)$ & & \\
\hline 0.0063 & & & & & & & 89. & $(77)$ \\
\hline 0.005 & 79.3 & $(87)$ & 10.4 & (106) & 3.0 & $(100)$ & & \\
\hline 0.0031 & & & & & & & 27. & $(70)$ \\
\hline 0.0025 & 32.6 & $(86)$ & 2.7 & $(112)$ & 2.7 & $(75)$ & & \\
\hline 0.0016 & & & & & & & & $(75)$ \\
\hline 0.0013 & 4.5 & $(89)$ & 0.9 & $(108)$ & 1.3 & $(79)$ & & \\
\hline 0.00078 & & & & & & & & $(79)$ \\
\hline 0.00062 & 1.4 & $(71)$ & & & & & & \\
\hline 0.00039 & & & & & & & 0 & $(76)$ \\
\hline Control & 0 & (57) & 0 & $(60)$ & 0 & (86) & 0 & $(72)$ \\
\hline $\mathrm{LC}_{50}(\mathrm{ppm})$ & 0.00 & 32 & 0.01 & & 0.02 & & & 037 \\
\hline
\end{tabular}

Figure in parenthesis is a number of larvae tested. 
ppm for fenitrothion and $0.025 \mathrm{ppm}$ for fenthion. All the larvae were killed at 0.013 ppm of chlorpyrifos-methyl, $0.04 \mathrm{ppm}$ of temephos and $0.08 \mathrm{ppm}$ of fenitrothion.

Table 3 gives the results of laboratory tests of methoprene against $A n$. sundaicus immatures. Methoprene formulation showed higher efficacy $\left(\mathrm{IC}_{50}=0.00004 \mathrm{ppm}\right)$ than its technical grade $\left(\mathrm{IC}_{50}=0.00009 \mathrm{ppm}\right)$.

\section{Field trial of temephos 5\% wp}

Figure 2 shows the prevalence of larval densities in 9 ponds, $\mathrm{A}-\mathrm{I}$, in the first field trial with temephos $5 \%$ wp. The average density in untreated ponds $\mathrm{A}$ and I fluctuated between 0 and 14.0 individuals per 20 dips with an average of 2.31. At the nights of 23 and 24 October, brackish water invaded all the test ponds as the results of onset of high tides. Rapid decrease in larval densities was observed in all the ponds except 3 ponds $\mathrm{B}, \mathrm{E}$ and $\mathrm{F}$ from 23 to 24 October, suggesting that the brackish water flushed away mosquito larvae in the ponds.

After the first application, the average larval density in 3 treated ponds, B, E and F, and the density in a treated pond, $\mathrm{C}$, decreased to almost zero while those in untreated ponds $\mathrm{A}$ and I were rather stable, remaining at a low level. The average density in ponds $\mathrm{D}, \mathrm{G}$ and $\mathrm{H}$ was very low during the same period, although the first application was not made to these ponds, suggesting that the larvae were again flushed away by the second invasion of brackish water at the night of 24 October or they were killed with temephos contained in water which invaded from temephos-treated ponds into untreated ponds. The reappearance of larvae was not observed until 13th day after treatment in ponds $\mathrm{B}, \mathrm{E}$ and $\mathrm{F}$, and until 22nd day in pond $\mathrm{C}$.

After the second application, the average density in ponds $\mathrm{D}, \mathrm{G}$ and $\mathrm{H}$ decreased drastically, and low density was maintained in ponds $\mathrm{B}, \mathrm{E}$ and $\mathrm{F}$. The reappearance of larvae was not observed until 9th day after application in ponds $\mathrm{B}, \mathrm{E}$ and $\mathrm{F}$, and until 13th day in ponds $\mathrm{D}, \mathrm{G}$ and $\mathrm{H}$.

The results in the second trial are presented in Fig. 3. The average larval density in treated four ponds decreased to almost zero while it increased drastically in untreated four ponds after the application. Low density in the treated ponds and high density in the untreated ones were observed in 5 times survey for 15 days after the application.

Figure 4 illustrates the prevalence of larval densities in treated $\mathrm{K}$ and untreated $\mathrm{L}$ ponds in the third trial. After the application, the density decreased rapidly to zero in the treated pond, and the reappearance of larvae was not recorded until 30th day after application. The larval density in the untreated pond, on the contrary, fluctuated between 2 and 15 with an average of 7.2 during the period from 15 to 27 November 1984, and

Table 3 Efficacy of methoprene against Anopheles sundaicus immatures in laboratory tests.

\begin{tabular}{|c|c|c|c|c|c|c|}
\hline \multirow{2}{*}{$\begin{array}{l}\text { Concentration } \\
\text { of chemical } \\
(\mathrm{ppm})\end{array}$} & \multicolumn{3}{|c|}{ Methoprene technical grade } & \multicolumn{3}{|c|}{ Methoprene formulation (Altosid 10F) } \\
\hline & No. tested & $\begin{array}{l}\text { Emergence } \\
\text { rate }(\%)\end{array}$ & $\begin{array}{l}\text { Inhibition } \\
\text { rate }(\%)\end{array}$ & No. tested & $\begin{array}{l}\text { Emergence } \\
\text { rate }(\%)\end{array}$ & $\begin{array}{l}\text { Inhibition } \\
\text { rate }(\%)\end{array}$ \\
\hline 0.001 & 64 & 0 & 100 & 72 & 0 & 100 \\
\hline 0.0005 & 69 & 5.8 & 94.0 & 78 & 0 & 100 \\
\hline 0.00025 & 83 & 25.3 & 73.7 & 85 & 5.9 & 94.0 \\
\hline 0.00013 & 85 & 36.5 & 62.1 & 76 & 32.9 & 66.5 \\
\hline 0.000063 & 85 & 64.7 & 32.7 & 71 & 39.4 & 59.9 \\
\hline 0.000031 & 75 & 60.0 & 37.6 & 58 & 69.0 & 29.8 \\
\hline 0.000016 & 84 & 71.4 & 25.8 & 66 & 93.9 & 4.5 \\
\hline 0.0000078 & 61 & 77.0 & 20.0 & - & - & - \\
\hline Control & 79 & 96.2 & - & 60 & 98.3 & - \\
\hline $\mathrm{IC}_{50}(\mathrm{ppm})$ & & & 0.00009 & & & 0.00004 \\
\hline
\end{tabular}



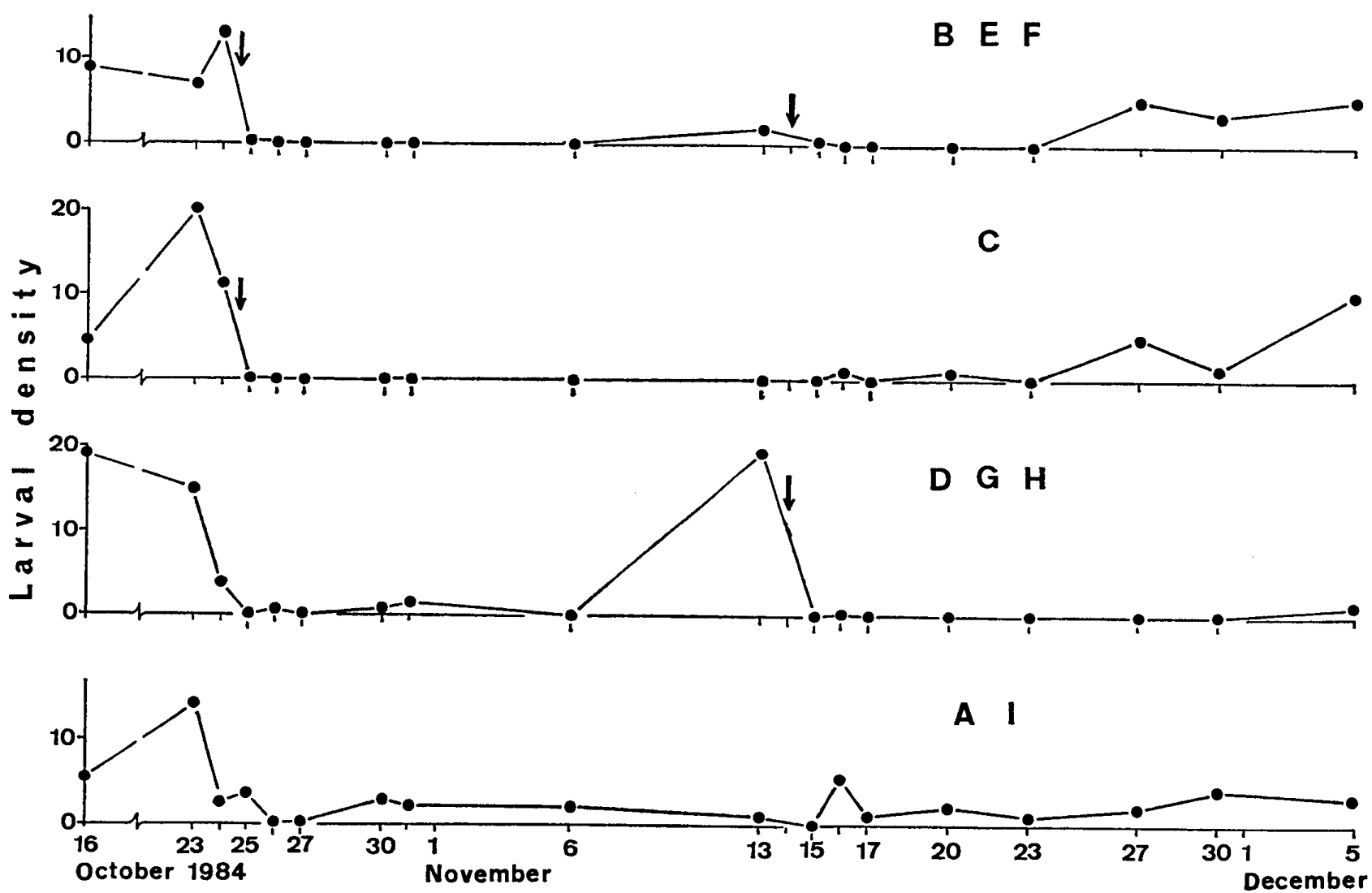

Fig. 2 Results of first field trial with temephos $5 \%$ wp in 9 ditch type ponds.

Each larval density means an average number of larvae collected per 20 dips in each of 4 pond groups shown by B E F ( 3 ponds), G ( 1 pond), DG H ( 3 ponds) and A I (2 ponds). Arrows imply application.

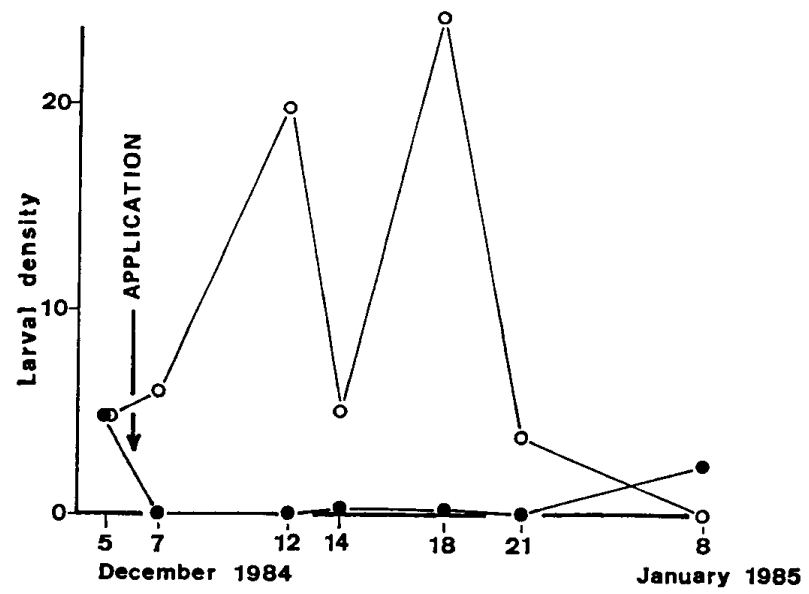

Fig. 3 Results of second field trial with temephos $5 \%$ wp in 8 ditch type ponds. Each larval density means an average number of larvae collected per 20 dips in each of 2 pond groups. larval density in 4 treated ponds $(\mathrm{D}, \mathrm{E}, \mathrm{G}, \mathrm{H}), \mathrm{O}$ larval density in 4 untreated ponds (A, B, C, F). thereafter remained at a lower level.

3. Field trial of fenitrothion 50\% EC and chlorpyrifos-methyl 5\% wp

Table 4 presents larval densities before and after the application of fenitrothion and chlorpyrifos-methyl.

In the field trial with fenitrothion, the density decreased to zero 1 day after treatment. The 1st and 2nd instar larvae were observed with a high density on 5th day, and all stages of larvae were observed with an extremely high density on 14 th day after treatment.

The larval densities decreased to zero 1 day after treatment in two ponds treated with chlorpyrifos-methyl. The young larvae were observed with a low densities on 7 th day after treatment. The old larvae were observed on 12 th day. The complete recovery of larval population was attained in pond $\mathrm{N}$ by 21 st day. 


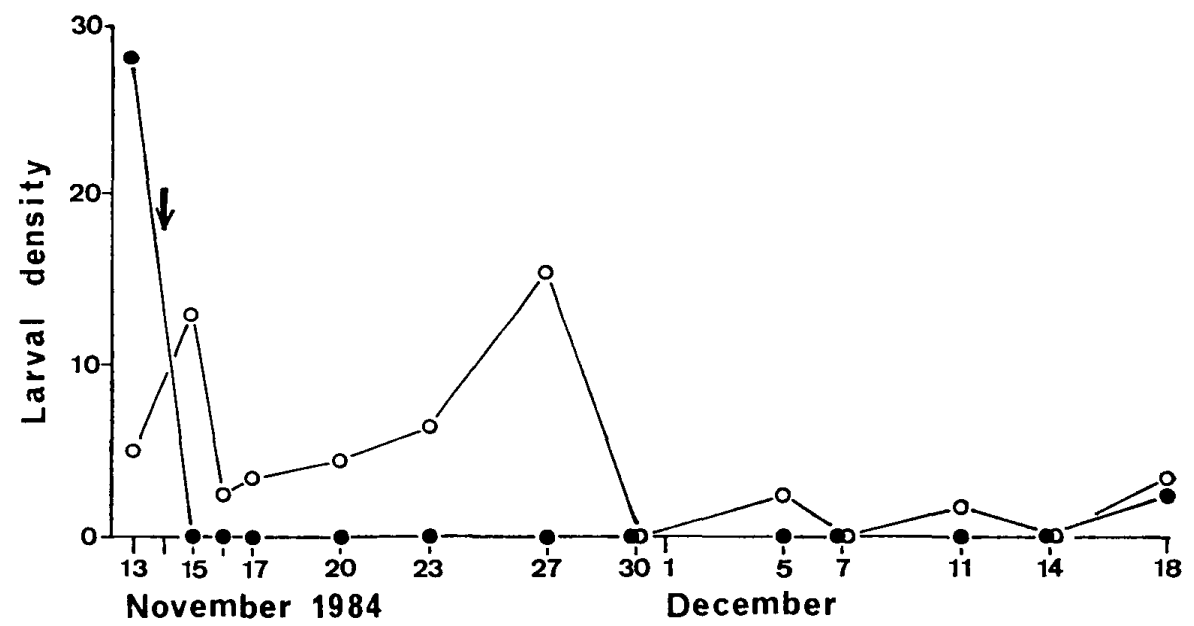

Fig. 4 Results of third field trial with temephos $5 \%$ wp in 2 ponds. - : larval density (No./20 dips) in a treated pond $\mathrm{K}, \bigcirc$ : larval density in an untreated pond L. Arrow implies application.

Table 4 Results of field application of fenitrothion and chlorpyrifos-methyl at Perupuk village.

\begin{tabular}{|c|c|c|c|c|c|c|c|c|c|c|c|}
\hline \multirow{3}{*}{ Date } & \multicolumn{4}{|c|}{ Fenitrothion } & \multicolumn{7}{|c|}{ Chlorpyrifos-methyl } \\
\hline & \multirow{2}{*}{$\begin{array}{l}\text { Days after } \\
\text { application }\end{array}$} & \multicolumn{3}{|c|}{ Larval density } & \multirow{2}{*}{$\begin{array}{l}\text { Days after } \\
\text { application }\end{array}$} & \multicolumn{3}{|c|}{$\begin{array}{l}\text { Larval density } \\
\text { (pond } M \text { ) }\end{array}$} & \multicolumn{3}{|c|}{$\begin{array}{l}\text { Larval density } \\
\text { (pond N) }\end{array}$} \\
\hline & & Young & Old & Total & & Young & Old & Total & Young & Old & Total \\
\hline 21 May & (Pre) & 157 & 107 & 264 & (Pre) & 121 & 69 & 190 & 96 & 53 & 149 \\
\hline 4 June & & & & & (Pre) & 130 & 110 & 241 & 104 & 83 & 187 \\
\hline 5 June & & & & & 0 & \multicolumn{3}{|c|}{ (Application) } & \multicolumn{3}{|c|}{ (Application) } \\
\hline 6 June & & & & & 1 & 0 & 0 & 0 & 0 & 0 & 0 \\
\hline 11 June & (Pre) & 189 & 143 & 332 & & & & & & & \\
\hline 12 June & 0 & \multicolumn{3}{|c|}{ (Application) } & 7 & 2 & 0 & 2 & 2 & 0 & 2 \\
\hline 13 June & 1 & 0 & 0 & 0 & & & & & & & \\
\hline 17 June & 5 & 163 & 0 & 163 & 12 & 15 & 6 & 21 & 20 & 3 & 23 \\
\hline 26 June & 14 & 867 & 499 & 1,366 & 21 & 42 & 0 & 42 & 1,017 & 271 & 1,288 \\
\hline
\end{tabular}

Young larvae: 1st and 2nd instars. Old larvae: 3rd and 4th instars. Larval density: Number of larvae collected per 20 dips.

Table 5 Effect of a methoprene formulation (Altosid 10F) against Anopheles sundaicus immatures in field tests.

\begin{tabular}{|c|c|c|c|c|c|c|}
\hline \multirow{3}{*}{$\begin{array}{c}\text { Days or weeks } \\
\text { after } \\
\text { application }\end{array}$} & \multicolumn{6}{|c|}{ Percentage of emergence inhibition } \\
\hline & \multirow{2}{*}{$\begin{array}{l}\text { Shallow } \\
\text { flood } \\
\text { field J }\end{array}$} & \multicolumn{4}{|c|}{ Artificial irrigation ditches } & \multirow{2}{*}{$\begin{array}{c}\text { Control } \\
\text { Ponds K, L }\end{array}$} \\
\hline & & Pond $\mathrm{E}$ & Pond $\mathrm{F}$ & Pond $\mathrm{G}$ & Overall & \\
\hline (Pre) & $1.4(220)$ & $7.9(114)$ & $5.6 \quad(90)$ & $11.6 \quad(43)$ & $7.7(247)$ & - \\
\hline 1 day & - & $(78)$ & (62) & (99) & $100 \quad(239)$ & $20.9(139)$ \\
\hline 1 week & $(100)$ & $(70)$ & (65) & $2 / 3$ & $99.3(138)$ & $17.7 \quad(17)$ \\
\hline 2 weeks & (110) & $90.3 \quad(176)$ & 96.2 & $91.2 \quad(68)$ & 92.7 (399) & $27.9 \quad(43)$ \\
\hline 3 weeks & (120) & $69.6(102)$ & $63.6 \quad(22)$ & $66.7 \quad(30)$ & $68.2(154)$ & 22.8 (114) \\
\hline 4 weeks & $(79)$ & $1 / 2 \quad(2)$ & $26.4 \quad(96)$ & $10.8 \quad(28)$ & $23.0(126)$ & $5.0 \quad(60)$ \\
\hline 5 weeks & $98.8 \quad(80)$ & $2 / 5$ & $10.7 \quad(75)$ & $24.0(104)$ & 19.'0 (184) & $12.7 \quad(63)$ \\
\hline 6 weeks & $0.8(121)$ & - & - & - & - & - \\
\hline
\end{tabular}

Figure in parenthesis is a number of immatures tested. 
4. Field trial of methoprene $10 \%$ flowable formulation

Table 5 and Fig. 5 show the results of field tests on the efficacy of methoprene against $A n$. sundaicus immatures. In three ponds $\mathrm{E}, \mathrm{F}$ and $\mathrm{G}, 100 \%$ emergence inhibition was observed 1 day after application. Thereafter the over-all inhibition rate decreased gradually: 1 week later to $99.3 \%$; 2 weeks, $92.7 \% ; 3$ weeks, $68.2 \% ; 4$ weeks, $23.0 \%$; and 5 weeks, $19.0 \%$. In a flood field type pond, J, $100 \%$ inhibition was observed for 4 weeks, and $98.8 \%$ inhibition was recorded 5 weeks after the application.

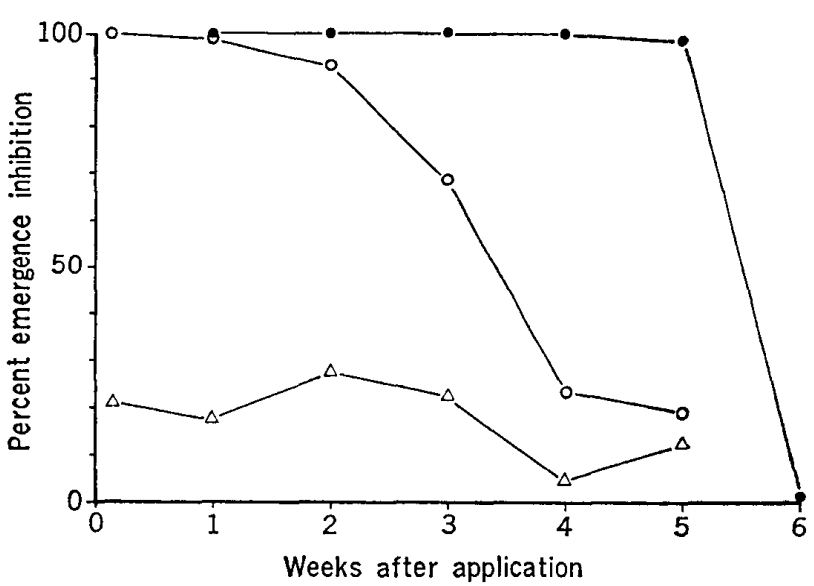

Fig. 5 Results of field trial with methoprene $10 \%$ flowable formulation.

- : emergence inhibition rate in a treated shallow flóod field $(J)$. $O$ : overall emergence inhibition rate in 3 treated ditch type ponds $(\mathrm{E}, \mathrm{F}, \mathrm{G}) . \Delta$ : emergence failure rate in 2 untreated ponds $(\mathrm{K}, \mathrm{L})$.

\section{Discussion}

1. Susceptibility of An. sundaicus larvae in Perupuk village. Ikemoto et al. (1986) reported that $\mathrm{LG}_{50}$ values to $A n$. sundaicus 4th instar larvae in Perupuk village, the same locality as the present study, were $0.0034 \mathrm{ppm}$ for temephos and $0.1176 \mathrm{ppm}$ for B.t.i. in 1983. They also suspected $\mathbf{I C}_{50}$ of methoprene for larvae to be less than $0.0004 \mathrm{ppm}$, basing on their preliminary results. The $\mathrm{LC}_{50}$ value of temephos in this study was almost same as in their report. Thus it is considered by comparing their results and ours that the Perupuk population of An. sundaicus is most susceptible to methoprene, followed in the descending order of susceptibility by temephos $=$ chlorpyrifosmethyl $>$ fenitrothion $>$ fenthion.

Ong et al. (1981) reported the $\mathrm{LC}_{50}$ values for larvae of a strain of $A n$. sundaicus in Singapore as follows: $0.00057 \mathrm{ppm}$ for fenthion, $0.00058 \mathrm{ppm}$ for temephos and 0.065 ppm for fenitrothion. The North Sumatra (Perupuk) population seems to be less susceptible to temephos and fenthion but 4.3 fold susceptible to fenitrothion, compared with the Singapore population.

The $\mathrm{LC}_{50}$ values to an Indian population of An. stephensi were $0.001-0.0019 \mathrm{ppm}$ for temephos and $0.01-0.016 \mathrm{ppm}$ for fenitrothion (Das and Rajagopalan, 1979). This mosquito population was with a similar susceptibility status to $A n$. sundaicus in North Sumatra. The $\mathrm{LC}_{50}$ values to $A n$. culicifacies larvae were $0.00048 \mathrm{ppm}$ for temephos and $0.0015 \mathrm{ppm}$ for fenitrothion in India (Das et al., 1981) showing that this population was highly susceptible to the above two chemicals compared with $A n$. sundaicus in North Sumatra. Georghiou (1972) reported the $\mathrm{LC}_{\overline{5} 0}$ values for larvae of $A n$. albimanus collected from El Salvador in June 1970 as follows: $0.045 \mathrm{ppm}$ for fenitrothion, 0.025 $\mathrm{ppm}$ for fenthion and $0.005 \mathrm{ppm}$ for temephos. The above values of fenthion and temephos were similar to those for the same species in the same locality reported by Keppler et al. (1965). An. albimanus in El Salvador, however, was reported to be resistant to temephos with $\mathrm{LC}_{50}$ value of $0.125 \mathrm{ppm}$ in 1978 (Lowe et al., 1980).

The $\mathrm{IC}_{50}$ values of methoprene were 0.004 ppm for $A n$. quadrimaculatus in U.S.A. (Dame et al., 1976) and $0.0022 \mathrm{ppm}$ for An. dirus in Thailand (Phonchevin et al., 1985). The above values are much higher than that for $A n$. sundaicus in this study.

These comparisons suggest that the North Sumatra population of $A n$. sundaicus is highly susceptible to methoprene, susceptible to temephos and chlorpyrifos-methyl and a little tolerant to fenitrothion and fenthion.

2. Efficacy of field application of temephos $5 \%$ wp. The efficacy of temephos application in the 1st trial was not very clear because larval density was low even in untreated control ponds. It might be, 
however, concluded that reappearance of larvae was suppressed for at least 9 days in this trial. Temephos application in the 2nd trial was considered to be effective to suppress larval population for 15 days. Results of the 3rd trial showed that this application was effective for 13 days or longer. Thus temephos application was effective to suppress $A n$. sundaicus larvae in Perupuk ponds for at least 9 days.

Ikemoto et al. (1986) concluded that the practical efficacy against $A n$. sundaicus of temephos $5 \%$ wp applied at $1 \mathrm{ppm}$ concentration was maintained for at least 2 weeks in ditch type ponds in Perupuk village. Our study revealed that the $1 \mathrm{ppm}$ application of temephos was effective for at least 9 days in the Perupuk ponds of both ditch and flood field types. As stated by Ikemoto et al. (1986), we consider that the practical efficacy of temephos might be maintained for about 2 weeks, taking the developmental period of the immatures into account.

Temephos $50 \% \mathrm{EC}$ applied at $0.01 \mathrm{~g}$ a.i./ $\mathrm{m}^{2}$ completely suppressed anopheline larvae for 4 days in rice field in Malaysia (Yap et al., 1982). In Northern Nigeria, 1\% sand granules, $40 \% \mathrm{EC}$ and $1 \%$ floating granules of temephos prevented the reappearance of 1st instar larvae of An. gambiae for 7, 9 and 12-16 days, respectively, after $1 \mathrm{ppm}$ application onto test plots measuring $2 \mathrm{~m} \times 1 \mathrm{~m}$ by $15 \mathrm{~cm}$ depth. The $\mathrm{LC}_{50}$ value of temephos for the target species in this field trial was $0.0074 \mathrm{ppm}$ (Fontaine and Rosen, 1973). This result is similar to ours in susceptibility level of target species and efficacy of temephos applied. Lowe et al. (1980) reported that a $0.00092 \mathrm{~g}$ a.i. $/ \mathrm{m}^{2}$ application of temephos could not completely control $A n$. albimanus larvae in El Salvador even one day after application, and that the $\mathrm{LC}_{50}$ value of temephos was very high $(0.125 \mathrm{ppm})$ for the target species in 1978, two years after the application. This temephos resistance in the mosquito as well as relatively small dose of temephos applied might cause the failure in the above field trial.

3. Efficacy of field application of fenitrothion 50\% EC and chlorpyrifos-methyl 5\% $w p$. The fenitrothion application prevented reappearance of $3 \mathrm{rd}$ and 4 th instar larvae of An. sundaicus in Perupuk for at least 5 days. The adult emergence might be suppressed for at least 10 days, taking the developmental period of the immatures into consideration.

The chlorpyrifos-methyl treatment suppressed reappearance of $3 \mathrm{rd}$ and 4 th instar larvae for at least 7 days, and it appeared to prevent adult emergence for about 12 days.

Further studies are necessary to ascertain the efficacy of field application of these larvicides.

4. Efficacy of field application of methoprene $10 \%$ flowable formulation. If more than $90 \%$ emergence inhibition is supposed to be effective, the $1 \mathrm{ppm}$ application of methoprene to three ditch type ponds was considered effective for about 2 weeks, and the application for a natural flood field was proven effective for 5 weeks at a target dose of $0.062 \mathrm{~g}$ a.i. $/ \mathrm{m}^{2}$. If the average water depth of the flood field is placed to be $10-20 \mathrm{~cm}$, the concentration of methoprene per water body is estimated to be $0.3-0.6$ ppm. Thus the application of methoprene to the flood field is considered much more effective at about a half concentration, compared with the application to the artificial ditches. The reason for the above difference of efficacy between two types of water body is unknown but it will be worth to note that the water depth of the flood field was shallower than those of the artificial ditches, yet it can be concluded that the efficacy of field applied methoprene remained for at least 2 weeks under the conditions in Perupuk village.

\section{Acknowledgements}

We wish to express our sincere thanks to Dr. Hariadi, Chief of Provincial Health Service of North Sumatra, and Dr. T. Suzuki, JICA Team Leader of North Sumatra Health Promotion Project for their support and valuable advices during the course of our study. Our thanks are also due to Mr. W. Pohan, Mr. H. Sirait and Mr. H. Hasibuan in Vector Borne Disease Control Section, Provincial Health Service of North Sumatra for their good assistance in the field survey. We are grateful to Dr. M. Yasuno, National Institute for Environmental Studies, Japan, for his kind guidance to the planning of this study and critical reading of this manuscript. 


\section{REFERENGES}

Dame, D. A., R. E. Lowe, G. J. Wichterman, A. L. Cameron, K. F. Baldwin and T. W. Miller (1976): Laboratory and field assessment of insect growth regulators for mosquito control. Mosq. News, 36: 462-472.

Das, P. K. and P. K. Rajagopalan (1979): Susceptibility of larvae of Culex fatigans (Wiedmann), Anopheles stephensi (Liston) and Aedes aegypti (Linn.) to insecticides in Pondicherry. Indian J. Med. Res., 70: 412-416.

Das, P. K., T. Mariappan and N. Somachary (1981): Susceptibility of Pondicherry strain of Anopheles culicifacies Giles to different insecticides. Indian J. Med. Res., 74: 385-387.

Fontaine, R. E. and P. Rosen (1973): Evaluation of Abate insecticide formulations as larvicides against Anopheles gambiae in Northern Nigeria. Mosq. News, 33: 428-440.

Georghiou, G. P. (1972): Studies on resistance to carbamate and organophosphorus insecticides in Anopheles albimanus. Am. J. Trop. Med. Hyg., 21 : 797-806.

Ikemoto, T. (1982): Studies on the bionomics of Anopheles sundaicus (Rodenwaldt, 1925), the principal malaria vector in a coastal area of North Sumatra, Indonesia. Teikyo Med. J., 5: 1-15.

Ikemoto, T., Sumitro, W. Panjaitan and T. Shibuya (1986): Laboratory and small-scale field tests of larvicides and larvivorous fishes against Anopheles sundaicus larvae at Perupuk Village, North Sumatra, Indonesia. Jpn. J. Sanit. Zool., 37: 105-112.

Kanbara, H. and W. Panjaitan (1983): The epidemiological survey of malaria in Asahan district, North Sumatra, Indonesia. Jpn. $J$. Trop. Med. Hyg., 11: 17-24.

Keppler, W. J., W. Klassen and J. B. Kitzmiller (1965) : Laboratory evaluation of certain larvicides against Culex pipiens, Linn., Anopheles albimanus Wied. and Anopheles quadrimaculatus Say. Mosq. News, 25: 415-419.

Lien, J. G., L. Kosman, F. Partono, Arbain Joesoef, E. Kosin and J. H. Cross (1975): A brief survey of mosquitoes in North Sumatra, Indonesia. J. Med. Entomol., 12: 233-239.

Lowe, R. E., J. E. Fowler, C. S. Lofgren, D. A. Dame, K. E. Savage and D. L. Bailey (1980): Field and laboratory assessment of temephos for larval control of Anopheles albimanus in El Salvador and evidence for resistance. Mosq. News, 40: 418-423.

Ong, K. H., L. M. Chew and K. L. Chan (1981) : Current insecticidal susceptibility status of mosquitoes in Singapore. Southeast Asian J. Trop. Med. Public Health, 12: 222-227.

Phonchevin, T., E. S. Upatham, B. Phanthuma- chinda, C. Prasittisuk and N. Sukhapanth (1985): Effects of cyromazin and methoprene on the developmental stages of Anopheles dirus, Aedes aegypti and Culex quinquefasciatus (Diptera: Culicidae). Southeast Asian J. Trop. Med. Public Health, 16: 240-247.

Schaefer, C. H. and S. Kirnowardoyo (1983): An operational evaluation of Bacillus thuringiensis serotype H-14 against Anopheles sundaicus in West Java, Indonesia. Mosq. News, 43: 325-328.

Sudomo, M., S. Aminah, H. Mathis and Y. H. Bang (1981): Small-scale field trials of Bacillus thuringiensis $\mathrm{H}-14$ against different mosquito vector species in Indonesia. $\mathrm{WHO} / \mathrm{VBC} /$ 81. 836: 1-10.

Sundararaman, S., R. M. Soeroto and M. Siran (1957): Vectors of malaria in Mid-Java. Indian J. Malariol., 11: 321-338.

Swellengrebel, N. H. and E. Rodenwaldt (1932): Die Anophelen von Niederlandisch-Ostindien, 242 pp., Verlag von Gustav Fischer, Jena (cited from Lien et al., 1975).

ten Houten, A., N. Siti Aminah, T. Suroso and I. G. Seregeg (1980) : Effects of diflubenzuron (OMS 1804) against malaria vectors breeding in lagoons in Bali, Indonesia. $\mathrm{WHO} / \mathrm{VBC} / 80$. 795: 1-7.

Yap, H. H., B. L. Lau and Y. P. Leong (1982) : Laboratory and field tests of temephos (Abate $(B)$ on mosquito larvae and non-target organisms in rice fields in Malaysia. Southeast Asian J. Trop. Med. Public Health, 13: 646-653.

\section{摘 要}

インドネシア国北スマトラ州の 1 村落の Anopheles sundaicus に対する数種殺幼 虫剤の室内および野外試験における効力

インドネシア国北スマトラ州の 1 海岸村落に生息す るマラリア媒介蚊 Anopheles sundaicus の幼虫に対 する数種薬剤の効力を，日本・インドネシア共同，北 スマトラ地域保健プロジェクトの一環として，1984〜 1985 年に調べた. 4 齢幼虫に対する LC $_{50}$ あるいは $\mathrm{IC}_{50}$ は temephos: $0.0032 \mathrm{ppm}$, chlorpyrifos-methyl : $0.0037 \mathrm{ppm}$, fenitrothion: $0.015 \mathrm{ppm}$, fenthion: $0.025 \mathrm{ppm}$, methoprene: $0.00009 \mathrm{ppm}$ であった. temephos $5 \%$ 水和剤を $1 \mathrm{ppm}$ の濃度になるように 幼虫の生息池 8 力所に処理したところ，少なくとも 9 日間幼虫の個体群密度を抑圧できた。 chlorpyrifosmethyl 5\% 水和風は, $1 \mathrm{ppm}$ の処理で 7 日間幼虫密 度を抑圧した。しかし， fenitrothion 50\% 乳剂の効果 は，1 $1 \mathrm{ppm}$ 処理で 4 日もしくはそれより短期間しか 持続しなかった. methoprene 10\% 製剤 (Altosid 10F) は， $1 \mathrm{ppm}$ の濃度で人工水路に処理すると，2 週間後まで $90 \%$ 以上の羽化阻止効果を示し，水深の 浅い汇濫原では, $0.062 \mathrm{~g}$ a.i. $/ \mathrm{m}^{2}$ の処理量で 4 週間後 まで 100\%の羽化阻止効果を発揮した。 